\title{
Kemampuan Ekstrak Daun Mimba (Azadirachta Indica) Menekan Populasi Wereng Batang Cokelat (Nilaparvata Lugens) Pada Tanaman Padi
}

\author{
Martua Suhunan Sianipar ${ }^{1)}$, Lucyana Jaya ${ }^{1)}$, Roynaldi Sinaga ${ }^{2)}$ \\ ${ }^{1)}$ Staff Pengajar Departemen HPT Fakultas Pertanian Universitas Padjadjaran. \\ ${ }^{2)}$ Alumni Departemen HPT Fakultas Pertanian Universitas Padjadjaran. \\ Korespondensi: $\underline{\text { suhunan@unpad.ac.id }}$
}

\begin{abstract}
ABSTRAK
Wereng Batang Coklat (Nilaparvata lugens Stal) /WBC merupakan serangga hama utama pada tanaman padi. Pengendalian alternatif seperti pemanfaatan tumbuhan sedang digalakkan. Mimba merupakan pestisida nabati yang dapat mengendalikan serangga hama sehingga dapat digunakan sebagai pengendali OPT pada budidaya pertanian. Percobaan dilaksanakan di Rumah Kaca Fakultas Pertanian Universitas Padjadjaran, dirancang dalam rancangan acak kelompok dengan 5 perlakuan dan 5 ulangan. Perlakuan yang diujikan adalah konsentrasi ekstrak cair daun mimba yang diaplikasikan sebagai pestisida nabati pada tanaman padi yang diinvestasi WBC. Variabel pengamatan adalah : jumlah WBC yang mati. Hasil percobaan menunjukkan bahwa perlakuan ekstrak daun mimba mampu menekan populasi WBC. The use of neem steem extract for $10 \%$ could repress the highest WBC population with the $78 \%$ rate of mortality.
\end{abstract}

Kata kunci : Pestisida nabati Mimba, WBC, Tanaman Padi

\section{The Ability of Neem Leaf Extract (Azadirachta indica) To Suppres The Populationof Brown Planthopper (Nilaparvata lugens) On Rice Plant}

\begin{abstract}
Brown Planthopper (Nilaparvata lugens) is the main pest of rice plants. Alternative controls such as the use of plant extract are being promoted. Neem is a botanical pesticide using for insect pests control, and its anti- bacterial, insecticide, fungicide and nematicide activities has been using as a pest control agent in plant cultivation. The experiment was carried out in the Greenhouse of Faculty of Agriculture, Universitas Padjadjaran. The experiment was designed in the Randomized Block Design with 5 treatment and 5 replications. The treatment tested was the concentration of neem leaf extract. The Mortality of brown planthoppers was calculated based on the number of dead brown planthopper compared to the initial number. The results of the experiment showed that neem leaf extract was able to suppress the brown planthopper population. The ectract treatment at the $10 \%$ of concentration for Neem plants can reduce the population of brown planthopper for about $78 \%$.
\end{abstract}

Keyword : Azadiracta indica, Nilaparvata lugens, rice plant.

\section{PENDAHULUAN}

Tanaman padi (Oryza sativa L.) merupakan tanaman pangan yang menjadi bahan makanan pokok penduduk di dunia. Indonesia sebagai negara dengan jumlah penduduk yang besar menghadapi tantangan dalam memenuhi kebutuhan pangan penduduk. Oleh karena itu, kebijakan ketahanan pangan mejadi fokus utama dalam pembangunan pertanian. Menurut data BPS ${ }^{[1]}$, konsumsi beras pada tahun 2015 mencapai $1.631 \mathrm{~kg}$ kapita/minggu dengan jumlah penduduk 254.9 juta jiwa, sehingga konsumsi beras nasional pada tahun 2015 mencapai 84.812 ton. Kebutuhan beras akan terus meningkat seiring dengan laju pertumbuhan penduduk yang lebih cepat dari pertumbuhan produksi pangan yang tersedia ${ }^{[2]}$. Salah satu kendala dalam budidaya tanaman padi adalah 
adanya serangan hama. Wereng Batang Cokelat (Nilaparvata lugens Stal) disingkat WBC, merupakan salah satu hama utama pada tanaman padi yang penyebarannya ditemukan di India, Asia Tenggara dan Asia Timur ${ }^{[3]}$. Ledakan hama WBC disebabkan oleh penggunaan jenis insektisida yang tidak sesuai dengan dosis yang dianjurkan. Lebih $90 \%$ petani menjadi penyebab meningkatnya populasi WBC, ditambah lagi $71 \%$ dari jumlah petani tersebut masih menggunakan insektisida bukan anjuran. Hal tersebut disebabkan melemahnya disiplin monitoring hama WBC oleh petani yang menambah kerusakan tanaman padi ${ }^{[4]}$. Adapun dampak lain yang akan ditimbulkan apabila penggunaanya penggunaan pestisida sintetis tidak bijaksana diantaranya dapat mengganggu kesehatan manusia, serta mencemari lingkungan. Maka dari itu, penggunaan insektisida sintetik harus segera dikurangi dan beralih ke insektisida nabati yang relatif lebih murah, serta aman bagi kesehatan dan lingkungan $^{[5]}$. Insektisida nabati adalah insektisida yang bahan aktifnya menggunakan bahan alami yang berasal dari tumbuhan ${ }^{[6]}$. Mimba (Azadirachta indica A. Juss) merupakan pestisida bahan nabati yang memiliki kemampuan anti-bakteri, insektisida, fungisida, nematisida, dan virusida, sehingga dapat digunakan sebagai pengendali OPT pada budidaya pertanian.

Penelitian mengenai kemampuan ekstrak daun mimba menekan populasi WBC pada tanaman padi, perlu dilakukan untuk mencegah terjadinya pencemaran lingkungan dan bertujuan untuk mengetahui kemampuan dan konsentrasi yang dapat menekan populasi WBC.

\section{BAHAN DAN METODE}

Percobaan dilaksanakan di Rumah Kaca Hama dan Penyakit Tumbuhan Fakultas Pertanian, Jatinangor, 720 mdpl, pada bulan Februari 2018 sampai Mei 2018. Menggunakan daun mimba, air (sebagai pelarut), bibit padi varietas pelita yang berumur 21-30 hari, Nimfa WBC instar 3, tanah sawah, air, tween 80, dan etanol $96 \%$. Adapun alat yang digunakan adalah sungkup yang terbuat dari kain kasa, gunting, gelas ukur, evaporator, timbangan, hands prayer, spidol, blender, label nama, alat tulis, saringan, dan pot sebagai wadah tanaman padi.

Penelitian menggunakan Rancangan Acak Kelompok dengan 5 perlakuan dan 5 ulangan. Perlakuan yang diujikan adalah konsentrasi ekstrak cair daun mimba yang diaplikasikan sebagai pestisida nabati pada tanaman padi yang diinvestasiWBC, yaitu : $\mathrm{M}_{0}=$ Aquades steril/kontrol, tanpa ekstrak mimba, $\mathbf{M}_{1}=$ Ekstrak cair daun mimba konsentrasi 5,0\%, $\mathrm{M}_{2}=$ Ekstrak cair daun mimba konsentrasi 7,5\%, $\mathrm{M}_{3}=$ Ekstrak cair daun mimba konsentrasi $10 \%$, dan $\mathrm{P}_{1}=$ Pestisida sintetik Dimocell 400 SL (Dimehipo) konsentrasi $2 \mathrm{ml} / 1$ sebagai pembanding.

Setiap ulangan dalam 1 perlakuan terdiri dari 2 tanaman pada 2 pot yang terpisah. Data hasil penelitian dianalisis dengan analisis sidik ragam menggunakan aplikasi Minitab 18.0.

\section{Rearing Serangga Hama WBC}

Hama WBC diperoleh dari lapangan/ areal persawahan, dikembangbiakkan (rearing) di Rumah Kaca Hama Fakultas Pertanian. Rearing dilakukan dengan cara mengumpulkannya pada tanaman padi varietas pelita (30 HST) dan ditutup dengan sungkup, lalu dibiarkan hingga WBC bertelur dan menetas.

\section{Pembuatan Sungkup Dan Pestsida Nabati Ekstrak Daun Mimba}

Sungkup terbuat dari plastik mika yang dibentuk meyerupai tabung, agar dapat menutupi tanaman padi dan WBC yang berada dalam pot yang berdiameter $25 \mathrm{~cm}$. Diameter sungkup harus lebih kecil dibandingkan diameter pot.Pembuatan pestisida nabati dilakukan dengan cara memisahkan daun dari rantingnya terlebih dahulu. Setelah itu daun mimba dikeringkan anginkan selama beberapa jam. Kemudian daun mimba diblender sampai 
halus, lalu hasilnya direndam dalam alkohol 70 $\%$ sebanyak 1 liter selama 24 jam pada sebuah wadah kaca. Setelah itu, hasil rendaman disaring menggunakan saringan. Pada hasil saringan dilakukan penguapan denganalat evaporator.Penguapan dilakukan hingga tersisa 0,5 bagian dari volume awal pada suhu $70^{\circ} \mathrm{C}$ selama 4 jam. Setelah penguapan selesai, maka didapatkan ekstrak pekat.

\section{Pengamatan}

\section{Mortalitas Serangga Hama WBC.}

Variabel yang diamati adalah mortalitas WBC. Jumlah WBC yang mati diamati selang 24 jam setelah pengaplikasikan pestisida nabati, dan selanjutnya setiap hari selama nimfa WBC masih ada yang hidup. Persentase mortalitas dihitung dengan rumus:

$$
\mathrm{M}=\frac{\text { Jumlah WBC yang mati }}{\text { Jumlah WBC yang diuji }} \times 100 \%
$$

Gejala pada WBC yang mati dapat dilihat dari ukuran dan warna tubuh WBC setelah diaplikasikan ekstrak daun mimba. Warna tubuh WBC yang terkena ekstrak daun mimba akan bewarna cokelat kehitaman. Ukurannya tidak akan mengalami pertambahan karena senyawa azadirachtin yang terkandung dalam ekstrak daun mimba memiliki aktivitas antifeedant yangmembuat WBC menjadi tidak makan sehingga proses pertumbuhan dan perkembangan WBC menjadi terhambat.

Pengamatan penunjang adalah pengamatan suhu dan kelembaban rumah kaca. Suhu dan kelembaban diukur dengan alat Termohigrometer yang diletakkan di rumah kaca. Pengamatan suhu dan kelembaban dilakukan setiap hari bersamaan dengan penghitungan jumlah serangga yang mati.

\section{Gejala Pada Serangga Hama WBC Yang} Mati.

Pengamatan perbedaan mortalitas serangga Hama WBC yang diberi perlakuan pestisida nabati ekstrak daun mimba dengan pestisida sintetis dilakukan dengan menggunakan mikroskop.

\section{HASIL DAN PEMBAHASAN}

\section{Mortalitas Wereng Batang Coklat}

Aplikasi ekstrak daun mimba pada beberapa taraf konsentrasi menunjukkan efek mematikan terhadap WBC. Berdasarkan Tabel 1, semua taraf konsentrasi ekstrak daun mimba yang diuji menyebabkan kematian WBC, mortalitas terendah terdapat pada konsentrasi $5 \%$, sedangkan konsentrasi $10 \%$ menyebabkan mortalitas yang tinggi.

Tabel 1. MortalitasWereng Batang Cokelat

\begin{tabular}{lcccccccc}
\hline \multirow{2}{*}{ Perlakuan } & \multicolumn{7}{c}{ Morlalitas WBC (\%) } \\
\cline { 2 - 9 } & $24 \mathrm{JSA}$ & $48 \mathrm{JS} \Lambda$ & $72 \mathrm{JSA}$ & $96 \mathrm{JS} \Lambda$ & $120 \mathrm{JS} \Lambda$ & $144-216 \mathrm{JS} \Lambda$ & Jumlah \\
\hline Kontrol & $0 \mathrm{c}$ & $0 \mathrm{c}$ & $0 \mathrm{~b}$ & $0 \mathrm{~b}$ & $0 \mathrm{~b}$ & 0 & $0 \mathrm{~d}^{*}$ \\
\hline Mimba $5 \%$ & $14 \mathrm{~b}$ & $13 \mathrm{~b}$ & $15 \mathrm{a}$ & $10 \mathrm{a}$ & $8 \mathrm{a}$ & 0 & $60 \mathrm{c}$ \\
\hline Mimba $7,5 \%$ & $17 \mathrm{~b}$ & $15 \mathrm{~b}$ & $16 \mathrm{a}$ & $11 \mathrm{a}$ & $10 \mathrm{a}$ & 0 & $69 \mathrm{bc}$ \\
Mimba $10 \%$ & $20 \mathrm{~b}$ & $18 \mathrm{~b}$ & $18 \mathrm{a}$ & $12 \mathrm{a}$ & $10 \mathrm{a}$ & 0 & $78 \mathrm{~b}$ \\
Dimehipo $2 \mathrm{ml} 1$ & $49 \mathrm{a}$ & $30 \mathrm{a}$ & $21 \mathrm{a}$ & - & - & 0 & $100 \mathrm{a}$ \\
\hline
\end{tabular}

Keterangan : * Nilai rata-rata yang diikuti huruf yang sama pada kolom yang sama menunjukkan tidak berbeda nyata menurut uji tukey pada taraf 5\%. JSA= Jam Setelah Aplikasi.

Pengamatan serangga dilakukan setiap hari dari hari ke-1 (24 jam) sampai hari ke-9 (216 jam) setelah aplikasi. Pada saat pengamatan WBC yang mati, nimfa WBC sudah berada pada instar ke- 4 pada waktu ke 48 JSA, instar ke- 5 pada waktu ke 96 JSA dan memasuki stadia imago pada waktu ke 144216 JSA. Perlakuan ekstrak daun mimba, 
membutuhkan waktu 5 hari (120 JSA) dalam membunuh WBC, dengan mortalitas yang dihasilkan tidak mencapai $100 \%$ pada akhir pengamatan. Pada perlakuan insektisida pembanding, pada hari ketiga sudah mencapai mortalitas $100 \%$. Diduga senyawa aktif yang terkandung dalam daun mimba bekerja secara lambat, dimana senyawa aktif ini membutuhkan waktu7-10 hari untuk dapat membunuh serangga secara langsung ${ }^{[7]}$. WBC yang telah mengkonsumsi senyawa aktif ek/strak daun mimba, daya hidupnya akan menurun.Hasil akhir percobaan menunjukkan persentasi mortalitas yang berbeda. Persentasi kematian WBC pada konsentrasi $10 \%$ lebih tinggi dibandingkan konsentrasi mimba lainnya walaupun tidak berbeda dengan konsentrasi 7,5\%. Hal ini dikarenakan semakin tinggi konsentrasi maka semakin tinggi juga tingkat kematian pada WBC seperti juga hasil penelitian lainnya bahwa semakin tinggi konsentrasi yang digunakan, maka kandungan bahan aktif dalam larutan lebih banyak sehingga daya racun pestisida nabatinya juga akan semakin tinggi ${ }^{[8]}$.

Data suhu dan kelembaban diukur dengan alat Thermohigrometer yang berada di rumah kaca. Selama percobaan berlangsung suhu minimum berkisar antara $10,4^{\circ} \mathrm{C}-19,4^{\circ} \mathrm{C}$, suhu maximum berkisar antara $28,0^{\circ} \mathrm{C}-30,4^{\circ} \mathrm{C}$ dan kelembaban rata-rata antara $85 \%-91 \%$. Hasil penelitian Widayani menunjukkan bahwa suhu penyimpanan $24,6^{\circ} \mathrm{C}-31,7^{\circ} \mathrm{C}$ dapat menyebabkan terurainya senyawa aktif pada mimba ${ }^{[9]}$. Nilaprvata lugens akan tumbuh dengan baik pada suhu $18^{\circ} \mathrm{C}-30^{\circ} \mathrm{C}$ dan kelembaban udara (RH) $70 \%-85 \%$ [10]. Berdasarkan data tersebut suhu dan kelembaban tidak menyebabkan kematian nimfa WBC. Pada suhu dan kelembaban tersebut populasi WBC dapat berkembang dengan cepat. Sehingga pada percobaan ini yang menyebabkan kematian WBC adalah ekstrak daun mimba.

\section{Gejala pada WBC yang Mati}

Pada saat dilakukan pengamatan dengan mikroskop, terdapat perbedaan warna tubuh dari WBC yang mati. WBC yang terkena ekstrak daun mimba menunjukkan warna tubuh cokelat agak kehitaman sedangkan WBC yang terkena pestisida sintetis menunjukkan warna tubuh cokelat terang (Gambar 1).

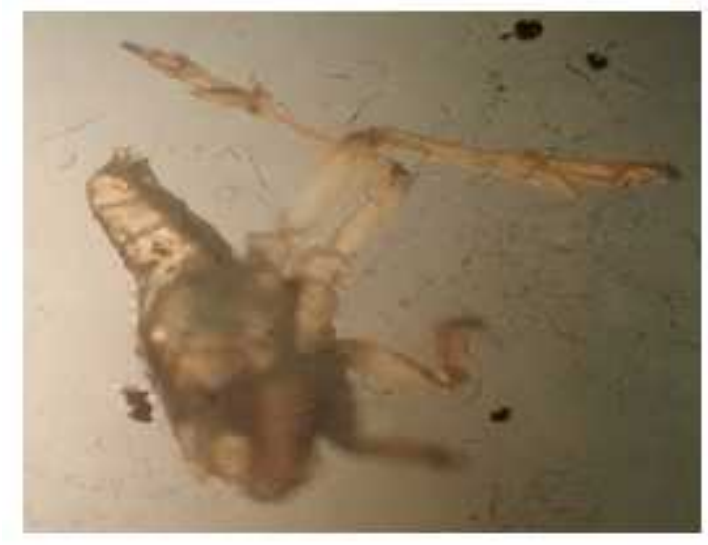

(a)

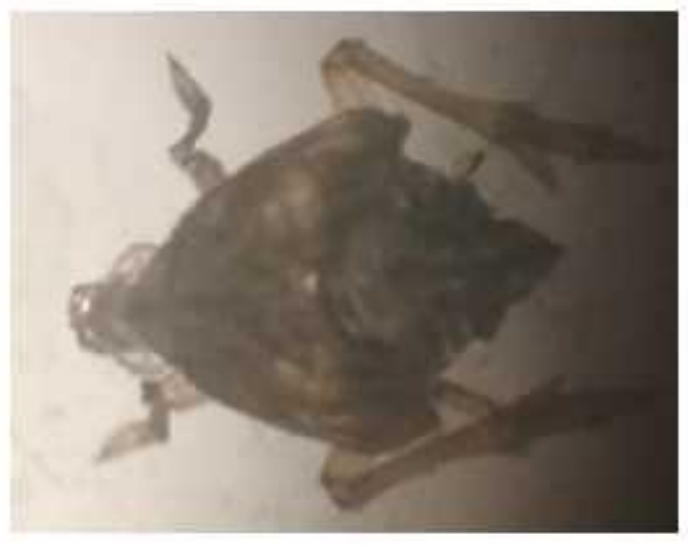

(b)

Gambar 1. Hama Wereng Coklat (WBC)

(a) WBC mati disebabkan pestisida sintetis;

(b) WBC mati disebabkan pestisida nabati 
Zat azadirachtin juga dapat menghambat pertumbuhan dan perkembangan serangga, sehingga WBC yang terkena ekstrak daun mimba tidak mengalami pertambahan ukuran tubuh. Zat azadirachtin memiliki aktivitas antifeedant, ketika larva serangga menelan senyawa azadirachtin maka senyawa tersebut dimuntahkan kembali ${ }^{[11]}$. Sehingga pertumbuhan dan perkembangannya terhambat karena adanya pemblokiran hormon biosintesis, seperti ecdisteroid. Azadirachtin juga berperan sebagai antifeedant dengan menghasilkan reseptor kimia (chemoreseptor) pada alat mulut (mouth part) yang mengganggu persepsi rangsangan untuk makan.

\section{KESIMPULAN}

Hasil penelitian disimpukan bahwa pemberian ekstrak daun mimba mampu menekan populasi Wereng Batang Cokelat. Pemberian dengan konsentrasi 10\% dan 7,5\% mampu menekan populasi masing-masing sebesar $69 \%$ dan78 \%, lebih tinggi dibandingkan dengan pemberian $5 \%$ yang hanya sebesar $60 \%$.

\section{DAFTAR PSTAKA}

[1] Badan Pusat Statistik. 2015. Produksi Tanaman Padi Seluruh Provinsi. http://bps.tnmnpgn.go.id. [09/02/2016].

[2] Anggraini F, Suryanto A, dan N. Aini. 2013. Sistem Tanam dan Umur Bibit pada Tanaman Padi Sawah (Oryza sativa L.) Varietas Inpari 13 Croping System And Seedling Age On Paddy (Oryza sativa L.) Inpary 13 Variety. Jurnal Produksi Tanaman, 1 (2): 52-60.

[3] Putra N, Martono E, dan S. Moeljopawiro. 2002. Seleksi Wereng Batang Padi Cokelat, Nilaparvata Lugens Stal. (Homoptera: Delphacidae) dengan Insektisida Karbamat MIPC dan
BPMC. Journal Agrosains, 3.

[4] Baehaki S dan I. Mejaya I. 2014. Wereng Cokelat sebagai Hama Global Bernilai Ekonomi Tinggi dan Strategi Pengendaliannya.

Pangan.Litbang.Pertanian.Go.Id, 9, Hal1-12. Retrieved from http://pangan.litbang.pertanian.go.id/file s/01-Iptek012014-Baehaki.pdf. [02/02/2018].

[5] Astuti U. P, Tri W, dan Bunaiyah, H. 2013. Petunjuk Teknis Pembuatan Insektisida Nabati. Balai Pengkajian Teknologi Pertanian Bengkulu. Bengkulu.

[6] Syakir, M. 2011. Status Penelitian Insektisida Nabati Pusat Penelitian dan Pengembangan Tanaman Perkebunan. Badan Litbang Pertanian.Dalam Seminar Nasional Pestisida Nabati IV pada 15 Oktober 2011. Jakarta..

[7] Ambarwati. 2011. Mimba sebagai Antibakteri, Antifungi, dan Biopestisida. Jurnal Kesehatan 4(2): 154-163.

[8] Prijono, D. 1994. Teknik Pemanfaatan Insektisida Proyek Botanis. Pembangunan Penelitian Pertanian NasionaI Fakultas Pertanian LPB. Balihort Lembang. Bogor. 40 pp.

[9] Widayani N. S, Haq A. N. and D. Dono. 2018. Testing The Effect of Temperature, Storage Time, The Residual Test of Neem Oil Formulation (Azadirachta indica) and Bitung Formulation (Baringtonia asiatica) to Its Toxicity Against Large Cabbage Heart Caterpillar (Crocidolomia pavonana $\mathrm{F}$ ) Jurnal Cropsaver, 1(1): 27-36.

[10] Harahap I. S dan B. Tjahjono. 1993. Pengendalian Hama dan Penyakit Untuk Padi. Penebar Swadaya. Bogor.

[11] Lee K, Singhal N. dan S Monica. 2010. Neem and Environment. World Neem, New Delhi. 14 pp. 